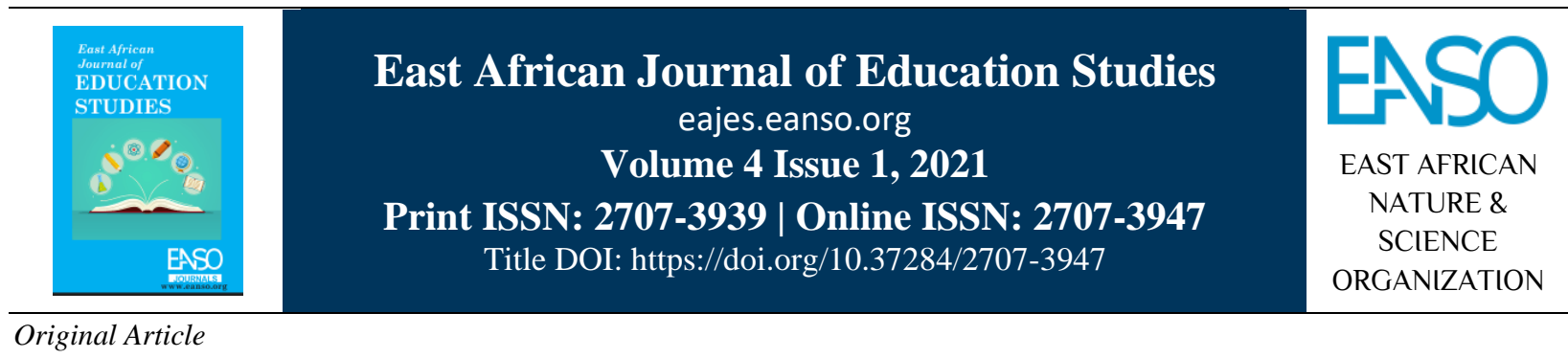

\title{
Provision of Quality Education in Public Early Childhood Education Centres in West Pokot County, Kenya.
}

\author{
Mildred Chebet Chepkonga, PhD \\ ${ }^{1}$ University of Eldoret, P. O. Box 1125-30100, Eldoret, Kenya. \\ * ORCID ID: https://orcid.org/0000-0001-8323-4774: Author for Correspondence Email: mchebet65@gmail.com.
}

Article DOI: https://doi.org/10.37284/eajes.4.1.432

\section{Date Published: ABSTRACT}

07 October 2021 There is a global emphasis on the importance of providing quality early childhood education and care to all children. The issue of provision of quality early childhood

Keywords: education for arid and semi-arid regions of Kenya has received less attention as it contributes to the status of literacy of the whole population. This paper looks at the

$E C D E$, provision of quality education in public early childhood education centres also Quality Education, known as pre-primary schools in West Pokot County, Kenya. The study Early Childhood

Education,

Numeracy, Literacy,

West Pokot County methodology incorporated qualitative and quantitative methods of research. This study took pragmatism as its philosophical paradigm. The study used a descriptive survey research design. The target population for the research involved 365 headteachers and 682 teachers. The sample size for the study was arrived at by taking $10-30 \%$ of the target population to act as the sample size that is $10 \%$ for headteachers and 30\% for ECDE teachers. The research instruments used were; questionnaires and interview guides. The data collected was analysed using qualitative and quantitative methods. Quantitative data was analysed using descriptive statistics such as frequencies, percentages, means and standard deviation. Statistical Package for Social Science (Version 20.0) helped in coding, entry and analysis. Qualitative data was analysed using content analysis method. The study found out that provision of quality education was at average level $(\mathrm{M}=2.87, \mathrm{SD}=1.13)$ in public pre-primary schools in West Pokot County. This means that half of the pupils in public pre-primary schools in the county are not receiving quality education and hence affecting their development in schools. Therefore, the paper recommends that adequate measures need to be put in place by the County Government of West Pokot County to ensure that public ECDE centres provide quality education through building more ECDE classrooms, employment of teachers on permanent and pensionable terms, provision of adequate instructional materials and meals programmes for remote schools to increase learners retention.

7 | This work is licensed under a Creative Commons Attribution 4.0 International License 
East African Journal of Education Studies, Volume 4, Issue 1, 2021

Article DOI: https://doi.org/10.37284/eajes.4.1.432

\section{APA CITATION}

Chepkonga, M. C. (2021). Provision of Quality Education in Public Early Childhood Education Centres in West Pokot County, Kenya. East African Journal of Education Studies, 4(1), 7-17. https://doi.org/10.37284/eajes.4.1.432.

\section{CHICAGO CITATION}

Chepkonga, Mildred Chebet. 2021. "Provision of Quality Education in Public Early Childhood Education Centres in West Pokot County, Kenya”. East African Journal of Education Studies 4 (1), 7-17. https://doi.org/10.37284/eajes.4.1.432.

\section{HARVARD CITATION}

Chepkonga, M. C. (2021) "Provision of Quality Education in Public Early Childhood Education Centres in West Pokot County, Kenya", East African Journal of Education Studies, 4(1), pp. 7-17. doi: 10.37284/eajes.4.1.432.

\section{IEEE CITATION}

M. C. Chepkonga, "Provision of Quality Education in Public Early Childhood Education Centres in West Pokot County, Kenya", EAJES, vol.4, no. 1, pp. 7-17, Oct. 2021.

\section{MLA CITATION}

Chepkonga, Mildred Chebet. "Provision of Quality Education in Public Early Childhood Education Centres in West Pokot County, Kenya". East African Journal of Education Studies, Vol. 3, no. 1, Oct. 2021, pp. 7-17, doi:10.37284/eajes.4.1.432.

\section{INTRODUCTION}

Early Childhood Development Education (ECDE) is the education given to young children (aged between 4 to 6 years) before the age of joining primary level education (6 years) (Obiweluozor, 2015). At the ECDE stage, children learn to share and co-operate with others (Chepkonga, 2017). They are taught how to understand and manage their emotions. They are also taught reading and writing tasks, are engaged in play activities for their psychomotor development among other activities stated in the pre-primary curriculum (Andiema, 2020). Statistical research has shown that children who have experienced early childhood are more likely to excel, remain in primary school and achieve good results than other children who have not gone through the same (UNESCO, 2013). This paper looks at the provision of quality education to ECDE children to ensure that they grow physically, emotionally and cognitively.

Sattar (2013) viewed quality as the appropriateness of resources available to education. It is also known that quality is the baseline standard in education that can be measured on a scale of reference. It is an expression of standard by which set standards in ECDE education can be achieved. Quality refers to the degree of excellence as measured against agreed-upon standards (Mwende, 2014). According to Kenya Sessional Paper No. 14 of 2012, the focus of quality in education is found in the learners admitted, the learning adopted and the academic staff in an institution (RoK, 2012). Quality education would refer to the degree of excellence in matters of learning and instruction reflected through the academic achievement of learners in schools. In many countries in the Sub-Saharan region, ECDE education is not part of the formal education system, governments do appreciate the value of quality ECDE and the sector is contained in official policy documents (UNESCO, 2013). An examination of official policy documents from many countries reveals that goals and objectives are clearly stated and are generally similar. They define goals and objectives of ECDE centres as offering non-formal education that aims at not only providing an allrounded development of children but also to prepare them for formal education (Mutuma, 2015). Research by Sifuna and Sawamura (2010) observed that despite efforts to promote ECDE in SubSaharan countries, access continues to be a significant challenge. Enrolment rates in ECDEs in the region are often below 10 percent, mainly due to limited facilities being available and the effect of poverty.

The Kenyan Constitution holds that every child has a right to free and compulsory basic education; and access to affordable tertiary education, training and skills development (RoK, 2010). Basic education covers two years of ECDE (Pre-Primary 1 to II), 8 years of primary education, 4 years of secondary education and 4 years of basic university degree (RoK, 2012). It can be seen that ECDE forms the foundation of education in Kenya, a focus of this study. The existing system of providing for early childhood education had been community-based for 
many years before 2013; it was managed by communities through their committees (Mwamba, 2013). Before the year 2013, 75\% of the ECDEs in Kenya were community-owned. However, the reforms in how ECDE was managed came into being through the enactment of the Kenyan Constitution in the year 2013. The Fourth Schedule, on the Distribution of Functions in the Constitution of Kenya (2010), allocated the responsibility of planning and development of pre-primary schools to County Governments. According to the schedule, the National Government shall retain responsibilities for policy, standards and curriculum development whereas the County Governments undertake implementation (RoK, 2010). The constitution required that making of curriculum to be done at the national level under KICD while implementation of ECDE curriculum to be done at the County level. This means that the effort of ensuring quality education is provided to ECDE learners rests on what happens at school level. Therefore, the issue of efforts made on ensuring quality education provision for ECDE learners is the focus of this study.

\section{PROBLEM STATEMENT}

The study was conducted in light of the challenges faced by public ECDE centres in the area that had affected the transition of pupils from one level (lower primary) to upper primary in West Pokot County which is low. Research reports show that majority of learners in West Pokot County transiting from ECDE to primary school level recorded low competencies in reading and writing tasks (Uwezo Kenya, 2015). Uwezo Kenya (2015) report noted that $41.31 \%$ of pupils in class three were able to read Hadithi (story) while more than half $68.69 \%$ were not able to read and write. Therefore, the research sought information from ECDE teachers and headteachers on quality ECDE provision in public ECDE centres in West Pokot County, Kenya.

\section{REVIEW OF LITERATURE}

The quality of education is an important issue all over the World (Sattar, 2013; Mwende, 2014). The term quality has been used interchangeably with the following nouns: efficiency, effectiveness, equity and quality have often been used interchangeably. Okebukola (2005) defines quality as the fitness of purpose. Ngware, Oketch and Ezeh (2011) contend that quality education comprises three interrelated aspects: Quality of human and material resources available for teaching (inputs); quality of teaching practice (process); and the quality of results (outputs and outcomes). On his part, Odhiambo (2008) opined that quality education is determined by the inputs such as curriculum content, instructional materials and equipment, school culture, teacherpupil ratio, costs and guiding policies, quality assurance, learning duration and above all the quality of the teachers and management functions. From these definitions, there was no consensus on the appropriate definition of quality education. However, there exists substantial agreement on dimensions of quality education. According to UNICEF (2000), this includes healthy, wellnourished and supporting learning facilities, environmental factors must be safe, protective and gender-sensitive, trained teachers and good methods for imparting knowledge and skill and adequate classroom and content, relevant curricula and skilful assessment.

In terms of goodness in performance, quality of education refers to excellence in performance through established acceptable criteria and standards of good performance (Mosha, 2000 as cited by Mwamba, 2013). However, standards are social and dynamic, they change with time and societies and hence they become value-laden (Sallis, 2002). In schools, achievements in examinations (Malekela, 2000) and learners' capabilities (Haki Elimu, 2007) are used as standards to assess the quality of education. High achievements refer to excellence in a program, a school or individual learners improvement (Manyanga, 2007). In other words, high achievements are used as standards to improve or upgrade the performance of individuals, both teachers and students in an institution (Lomas, 2007). This is evidenced in empirical studies. Abiero's (2013) study was to establish the overall parents' satisfaction with the quality of pre-primary education provided to their children in Bondo district, Kenya. Expectancy- Disconfirmation Theory of Customer Satisfaction was used as the basic theory of the study. The study employed a descriptive survey design. Results showed that most parents were somewhat satisfied with the quality of pre-primary education. T-test of independent 
samples found no significant difference in parents' satisfaction with the quality of pre-primary education by school type and parents' gender. One way Analysis of Variance found a significant difference in parents' satisfaction with the quality of pre-primary education by various levels of parents' education and income. This research looked at how quality education was viewed in West Pokot County.

\section{MATERIALS AND METHODS}

This research was conducted in West Pokot County, Kenya. In terms of research design, the study adopted a descriptive survey research design which enabled the collection of data using various instruments of qualitative and quantitative measures. The target population included all pubic primary headteachers (365) and ECDE teachers (682). In sampling, $30.0 \%$ of teachers were to be the sample resulting in 205 while $10 \%$ of the headteachers representing 37 were sampled. Headteachers and teachers were selected through stratified random sampling method. Data was collected via questionnaire and interview. Quantitative data collected was coded, recorded and analysed with the help of Statistical Package for the Social Sciences (SPSS) computer software (Version 23.0). Quantitative data was analysed by use of means; frequencies, percentages, means and standard deviation. Qualitative data from the interview guide was transcribed first and coded using numerals. Themes were merged with quantitative data in the results sections and presented after quantitative analysis.

\section{RESULTS AND DISCUSSIONS}

The main objective of this paper was to determine the level of provision of quality education in ECDE centres. The Government of Kenya and the County Governments have clear policy frameworks to guide the provision of quality education in ECDE. The policy has standards for quality and inclusive ECD services (Boke, 2014). It was important to determine how teachers rated the pupils' acquisition of several competencies in ECDE centres in West Pokot County in order to measure the provision of quality education. The teachers were supposed to rate ECDE pupils' competencies as very high, average, low, and very low. The results of the analysis are presented in Table 1.

Table 1: Provision of Quality Education in ECDE Centres

\begin{tabular}{|c|c|c|c|c|c|c|c|c|}
\hline Variable & & VH & $\mathbf{H}$ & $\mathbf{A}$ & $\mathbf{L}$ & VL & Mean & SD \\
\hline \multirow{2}{*}{ Pupil's acquisition of numeracy skills } & $\mathrm{f}$ & 5 & 21 & 56 & 92 & 31 & \multirow{2}{*}{2.4000} & \multirow{2}{*}{94765} \\
\hline & $\%$ & 2.4 & 10.2 & 27.3 & 44.9 & 15.1 & & \\
\hline \multirow{2}{*}{$\begin{array}{l}\text { Pupil's acquisition of reading and writing } \\
\text { skills }\end{array}$} & $\mathrm{f}$ & 23 & 64 & 90 & 15 & 13 & \multirow{2}{*}{3.3366} & \multirow{2}{*}{.98959} \\
\hline & $\%$ & 11.2 & 31.2 & 43.9 & 7.3 & 6.3 & & \\
\hline \multirow{2}{*}{$\begin{array}{l}\text { Pupils' ability to solve problems on their } \\
\text { own }\end{array}$} & $\mathrm{f}$ & 18 & 60 & 30 & 69 & 28 & \multirow{2}{*}{2.8585} & \multirow{2}{*}{1.23053} \\
\hline & $\%$ & 8.8 & 29.3 & 14.6 & 33.7 & 13.7 & & \\
\hline \multirow{2}{*}{$\begin{array}{l}\text { Pupil's level of creativity and imagination } \\
\text { in class }\end{array}$} & $\mathrm{f}$ & 9 & 18 & 32 & 79 & 67 & \multirow{2}{*}{2.1366} & \multirow{2}{*}{1.10297} \\
\hline & $\%$ & 4.4 & 8.8 & 15.6 & 38.5 & 32.7 & & \\
\hline \multirow{2}{*}{$\begin{array}{l}\text { Pupils interest in learning [coming to } \\
\text { school daily] }\end{array}$} & $\mathrm{f}$ & 50 & 76 & 39 & 18 & 22 & \multirow{2}{*}{3.5561} & \multirow{2}{*}{1.24972} \\
\hline & $\%$ & 24.4 & 37.1 & 19.0 & 8.8 & 10.7 & & \\
\hline \multirow{2}{*}{$\begin{array}{l}\text { Pupils transition rate from one level to } \\
\text { another }\end{array}$} & $\mathrm{f}$ & 7 & 19 & 97 & 58 & 24 & \multirow{2}{*}{2.6439} & \multirow{2}{*}{.92621} \\
\hline & $\%$ & 3.4 & 9.3 & 47.3 & 28.3 & 11.7 & & \\
\hline \multirow{2}{*}{$\begin{array}{l}\text { Pupils' performance in exams and } \\
\text { assessments }\end{array}$} & $\mathrm{f}$ & 20 & 43 & 67 & 45 & 30 & \multirow{2}{*}{2.8927} & \multirow{2}{*}{1.18330} \\
\hline & $\%$ & 9.8 & 21.0 & 32.7 & 22.0 & 14.6 & & \\
\hline \multirow{2}{*}{$\begin{array}{l}\text { Pupils' ability to work together in } \\
\text { teams/groups }\end{array}$} & $\mathrm{f}$ & 58 & 60 & 30 & 49 & 8 & \multirow{2}{*}{3.5415} & \multirow{2}{*}{1.23847} \\
\hline & $\%$ & 28.3 & 29.3 & 14.6 & 23.9 & 3.9 & & \\
\hline
\end{tabular}

Key: VH-Very High, H-High, A-Average, L-Low, VL-Very Low, f-frequency \& \%-percent

Findings on pupils' acquisition of numeracy skills from Table 1 shows that $92(44.9 \%)$ of teachers rated their pupil's numeracy skills as low and only $21(10.2 \%)$ rated them as high. From the result, it is 
evident that ECDE pupils' level of acquisition of numeracy skills in additions, subtraction, counting and multiplication was low $(M=2.4, S D=0.94)$ in public ECDE centres in West Pokot County. The result coincides with Jepleting's (2013), who found out that children performance in mathematics was low in ECDE centres. This result shows that pupils' level of arithmetic skills in the County is low.

On the pupils' acquisition of reading and writing skills, 90 (43.9\%) indicated pupils' competency as moderate and only 64 (31.2\%) said it was very high. From the findings, it can be deduced that pre-school children level of reading and writing was moderate $(M=3.33, S D=0.98)$ in public ECDE centres in West Pokot County. The research findings are in agreement with research by Abiero (2013) which established that parents in Bondo Sub County had confidence with the quality of their teachers, how children are taught and achievement; they were happier with the achievement of their children in reading than achievement in arithmetic and social skills. The results obtained suggest that since Uwezo report (2015), there has been significant improvement in investments in ECDE by the County Government raising the literacy level in the county to average level for the past four years (from 2015). Moreover, the above statistics can be explained by the fact that the environment (climatic and development) of the four Sub Counties under study are not similar. West and South Pokot are less arid while North and Central Pokot are semi-arid regions and have less development.

When asked to indicate pupils' ability to solve problems on their own, $69(33.7 \%)$ rated pupils' competency in problem-solving as low and 60 $(29.3 \%)$ rated them as high. From these results, it is seen that a significant number of pupils in preschool centres in West Pokot County cannot solve problems on their own while others can as evidence by the mean of 2.85 and standard deviation of 1.23. This could be due to the environment they receive instruction. The findings also show that 79 (38.5\%) of teachers indicated that their pupils' level of creativity and imagination was low and only 18 $(8.8 \%)$ said it was high. From the findings, it can be deduced that pupils' level of creativity and imagination in class is low $(M=2.13, S D=1.10)$. This could be due to the teaching approach being used in their classrooms and due to the lack of adequate instructional materials which are critical to pupils' development of creativity and imagination.

On pupils' school attendance resulting from their interest in learning, $76(37.1 \%)$ of teachers said it was high and only $22(10.7 \%)$ reported that school attendance was very low. This implies that the majority of pupils in Public ECDE centres interest in learning is high $(M=3.55, S D=1.24)$ and rarely miss coming to school. On the transition rate, 97 $(47.3 \%)$ indicated average transition while 24 $(11.7 \%)$ said it was very low. Based on the findings, the transition rate of pupils from one level to another in ECDE centres is average $(M=2.64, S D=0.92)$ suggesting that there exist challenges that affect the issue in public schools. The result coincides with responses made by some headteachers who gave different perceptions on Interview Question No. 2. For Instance, Headteacher thirteen (HT13) said that:

"The transition has been upward every year, there is an increase." Another Headteacher (HT2) indicated that: "The transition rate has been fluctuating due to the upcoming school in the neighbourhood." Similarly, another headteacher (HT25) also said that: "There has been a drop in transition over the years in my school." Still, another headteacher (HT10) had a different opinion compared to the other two (HT2 \& HT25) by indicating that: "There has been upward enrolment in the ECDE due to the centre around the school."

The responses made by headteachers confirm that transition challenges are prevalent in the majority of ECDE centres in West Pokot County. The transition challenges are mainly experienced when pupils enrol for standard one class. The method of instruction and environment is somehow different from what they used to experience in pre-school. For instance, desks and tables arrangement in preschools was round but in standard one, desks are arranged in rows. This setting in lower primary may affect pupils' transition. In addition, the availability of learning resources may also influence pupils' transition from pre-primary to primary school (Chepkonga, 2020). With regard to academic performance in exams and assessments, 67 (32.7\%) said the performance was average. It can be deduced that the performance of pupils in examinations is average $(M=2.89, S D=1.18)$ in a majority of schools while others perform poorly $(30.8 \%)$ and others (36.6\%) said it was high. Mwamba (2013) 
established that majority of learners were not satisfied with the administration of tests in their schools. This implies that irregular conduction of continuous assessment tests (CATs) in their schools affected their performance in examinations.

When asked the level at which pupils were able to work in teams and groups, $60(29.3 \%)$ said it was high. The results show that teachers have made significant efforts $(M=3.54, S D=1.23)$ to ensure cooperative learning takes place by allowing pupils to work together in teams and groups. Only 20 $(9.8 \%)$ teachers said that the quality of learning in their school was high, most 159 (77.6\%) said the quality was average and $26(12.7 \%)$ mentioned that quality was low from the data generated from SPSS on combined respondents' response. In conclusion to these findings, statistics show that provision of quality education in public ECDE centres was average $(M=2.92, S D=1.10)$ in West Pokot County. The findings concur with a study conducted by Abiero (2013) that showed that the level of parents' satisfaction with the quality of pre-primary education in Bondo District was low $(M=1.86$, $\mathrm{SD}=0.38$ ). This implies that a majority of preprimary school parents in Bondo district were somewhat satisfied with the quality of pre-primary education provided to their children. However, results are different from Olaleye and Omotayo (2009) study in Nigeria that showed that learning activities in the pre-primary schools selected was averagely high. This shows that disparity exists between Kenya and Nigeria in the provision of a conducive learning environment for learning in ECDE.

\section{CONCLUSION AND RECOMMENDATIONS}

The study has found out that the provision of quality education to ECDE pupils in West Pokot County is at average level. From the results presented, out of the eight constructs of quality education provision, only two were recorded to be high $(\mathrm{M}>3.5)$; pupils' interest in learning [coming to school daily] and pupils' ability to work together in groups. Four indicators of quality were rated to be on average level $(\mathrm{M}<3.5>2.5)$; pupils' ability to solve problems on their own, pupils transition rate from one level to another, pupils' acquisition of reading and writing skills and pupils performance in exams and assessments. The least quality indicators that were lowly ranked $(M<2.5)$ were; pupils' acquisition of numeracy skills and pupils' level of creativity and imagination in class. The above findings show that the achievement of quality education objectives is on average and therefore appropriate measures need to be taken by the county government, school management and other stakeholders to address issues that pre-primary schools are struggling with.

It is recommended that: more teachers should be employed on permanent and pensionable terms in the county; the county government should ensure that required resources and facilities for learning are provided in adequate quantity; teacher should be trained on instructional methodology and multistakeholder involvement in addressing quality issues facing ECDE schools in the area.

\section{REFERENCES}

Abiero, M. O. (2013). Parental Satisfaction with the Quality of Pre-Primary Education in Bondo District, Siaya County, Kenya. MED Thesis, Kenyatta University Kenya.

Andiema, N. C. (2020). Teachers competencies in evaluation of competency-based curriculum among special needs learners in Kenya. Global Journal of Educational Research, 19(2), 135145.

Boke, R. T. (2014). Implementation of Quality Services in Early Childhood Educational Institutions: A Case of Ntimaru Division, Kuria East District. MED Project, Kenyatta University, Kenya.

Chepkonga, M. C. (2017). Training Needs for Head-Teachers in Management of ECDE Curriculum Implementation in Primary Schools in Marakwet District, Kenya. American Based Research Journal, 6(8).

Chepkonga, M. C. (2020). The Instructional Learning Resources and Provision of Quality Education in public ECDE Centres in West Pokot County. JRDO - Journal of Educational Research, 5(1), 55-68. Retrieved from http://www.ijrdo.org/index.php/er/article/view/ 3454 
Haki Elimu (2007). Redefine Quality Education in Tanzania. From Input to Capabilities, Working Paper, October 2007 Dar-s salaam.

Jepleting, C. S. (2013). Effect of Classroom Environment on Academic Performance in Mathematics of ECDE Children in Pioneer Zone, Uasin Gishu County, Kenya. MED in ECDE Project, University of Nairobi, Kenya.

Lomas, L. (2007). Zen, Motorcycle Maintenance and Quality in Higher Education. Quality Assurance in Education, 15(4), 402-412.

Malekela, G. (2000). Quality of Secondary School Education in Tanzania. In J. C. J. Galabwa, F.M. K. Senkoro \& A.F. Lwaitama (eds). The Quality of Education in Tanzania: Issues and Experience; Faculty of Education, University of Dar-es-Salaam.

Manyanga, T. (2007). Standards for Quality in Tertiary Education: The Case of Tanzania. Quality Assurance in Education, 16 (20), 164180.

Mutuma, W. M. (2015). Effectiveness of Ministry of Education Efforts to Strengthen Early Childhood Education and Its Effect on Formal Education in Kenya. Riara University, Kenya.

Mwamba, Y. (2013). Role of School Based Factors on Quality of Education in Public Secondary Schools in Nyamira North District, Kenya. MED Project, University of Nairobi.

Mwende, L. D. (2014). School Based Factors Influencing Quality of Education in Public Secondary Schools in Kitui County, Kenya. MED Project, University of Nairobi.

Ngware, M. W., Oketch, M., \& Ezeh, A. C. (2011). Quality of primary education inputs in urban schools Evidence from Nairobi. Education and Urban Society, 43, 91-116. http://dx.doi.org/10.1177/0013124510379131.

Obiweluozor, N. (2015). Early Childhood Education in Nigeria, Policy Implementation: Critique and a Way Forward. African Journal of Teacher Education, 4, 1-9.
Odhiambo, G. (2008). Elusive Search for Quality Education: The case of quality assurance and teacher accountability. International Journal of Educational Management, 22(5), 417- 431.

Okebukola, P. (2005). Quality Assurance in Teacher Education: A Publication of the Committee of Deans of Education in Nigerian Universities.

Olaleye, O. F., \& Omotayo, K.A. (2009).Assessment of Quality in Early Childhood Education in Ekiti-State Nigeria. World Applied Sciences Journal, 7 (5), 683-688.

Republic of Kenya (2010). The Republic of Kenya Constitution. Nairobi: Government Press.

Republic of Kenya [RoK] (2012). A Policy Framework for Education: Aligning Education and Training to the Constitution of Kenya (2010) and Kenya Vision 2030 and beyond. Nairobi: Department of Education.

Sallis, E. (2002). Total Quality Management in Education. (3rd ed.). London: Kogan Page.

Sattar, A. K. (2013). Study to Investigate the Quality Of Education At Secondary Level In Khyber Pakhtunkhwa, Pakistan: A Survey Of Government Girls' Higher Secondary School. Universal Journal of Education and General Studies, 2(8), 276-284.

Sifuna, D. N. \& Sawamura, N. (2010). Challenges of Quality Education in Sub-Saharan AfricaSome Key Issues. Nova Science Publishers.

UNESCO (2013). Systematic Monitoring of Education For All: Education Indicators \& Data Analysis. Paris: UNESCO. Available online at www4.unescobkk.org.

UNICEF (2000). Defining Quality Education. Geneva: UNICEF.

Uwezo Kenya (2015). Are our Children Learning? Annual Learning Assessment Report. Nairobi: Uwezo Kenya. 